Article

\title{
The Effect of Modifiers and Method of Application on Fine-Coal Combustion
}

\author{
Wilhelm Jan Tic * and Joanna Guziałowska-Tic \\ Department of Environmental Engineering, Opole University of Technology, 45-758 Opole, Poland; \\ j.guzialowska-tic@po.edu.pl \\ * Correspondence: w.tic@po.edu.pl; Tel.: +48-77-449-8380
}

Received: 17 October 2019; Accepted: 28 November 2019; Published: 30 November 2019

\begin{abstract}
This research work presents the results of studies on the effect of modifiers comprising the salts $\mathrm{CuSO}_{4} \cdot 2 \mathrm{H}_{2} \mathrm{O}, \mathrm{NaCl}, \mathrm{NH}_{4} \mathrm{Cl}, \mathrm{MgSO}_{4} \cdot 7 \mathrm{H}_{2} \mathrm{O}, \mathrm{CaCl}_{2}$, and urea at various concentrations on the combustion of fine coal. The tests were carried out in a $12-\mathrm{kW}$ laboratory boiler equipped with a rotary-grate retort furnace. The emission levels and concentrations of $\mathrm{CO}, \mathrm{CO}_{2}, \mathrm{SO}_{2}, \mathrm{NO}_{\mathrm{x}}$, and TOC in the flue gas were measured using analyzers. A modifier composed of $350 \mathrm{ppm} \mathrm{Cu}, \mathrm{Na}, \mathrm{Mg}, \mathrm{NH}_{4}{ }^{+}$, $\mathrm{Ca}$, and urea showed particularly high activity in the combustion of fine coal. The flue-gas levels of $\mathrm{CO}, \mathrm{NO}_{x}$, and $\mathrm{SO}_{2}$ were reduced by approximately $9 \%, 12 \%$, and $10 \%$, respectively, in comparison with the modifier-free sample. In this case, the boiler efficiency also increased from $65 \%$ in the tests with no modifier to $76 \%$ in the tests with the modifier. The proprietary application system, enabling the modifier to be added in exact amounts to the variable flow of fine coal, is also described. It was found that the use of the modifier in coal combustion tests results in lower emissions of harmful fuel components, a higher amount of heat obtained from the fuel unit mass, lower corrosive impact of the fuels, lower boiler maintenance costs, and extended service life.
\end{abstract}

Keywords: combustion modifier; combustion; efficiency; emission; fine coal

\section{Introduction}

During the last few decades, the global population has nearly doubled. Consequently, energy consumption has increased considerably, in particular in connection with the latest technological developments. Though useful and comfortable, they are based on the limited and unsafe structures of energy generation, including fossil fuels, such as coal, petroleum, and gas [1,2]. The combustion of conventional sources of energy releases harmful substances, including $\mathrm{SO}_{2}, \mathrm{NO}_{\mathrm{x}}$, and $\mathrm{CO}$, as well as ash and dust particles. Wherever coal is used for generating energy, air and water pollution is much higher than the maximum permissible levels. Everywhere in the world, it is considered a fact that coal mining and the use of coal as a source of energy have an adverse environmental impact both locally and globally [3].

More than $38 \%$ of electric energy generated globally is based on coal $[4,5]$. Low costs of coal mining combined with high reserves of the raw material make it an attractive source of energy in emerging markets, such as India or China [6]. The total energy consumption in China was 3.164 million TCE (ton of standard carbon equivalent) in 2018 [7]; this was approximately $54 \%$ of the energy consumption in Asia and nearly one-fourth of the global consumption of energy [8]. However, China also generates the highest amount of $\mathrm{CO}_{2}$ in the world: In 2107, its share in global emissions was $27.21 \%$ [9]. The opposite trend is seen in developed countries, tending to increase the percentage of renewable energy in their total national consumption of energy. The share of renewable energy sources in global energy production was $26 \%$ in 2018 , which is $0.8 \%$ more than one year before [9]. 
In Poland, even as much as $80 \%$ of electric energy is still based on coal, including brown coal [10]. Looking at the latest investments in the power engineering industry in Poland, such as new power units in power plants, as well as the national energy policy, it seems that coal will continue to be the essential raw material in the generation of electric energy in Poland [10,11].

The growing mechanization of coal mining leads to an increased efficiency of the production of fine coal (grain size 0-20 mm). Small coal has a high content of sulfur; therefore, its direct combustion is a serious source of environmental pollution. Reasonable utilization of fine coal is important for sustained development in power engineering [12].

Direct coal combustion is a commonly used technology in the production of electric and thermal energy. There are essentially two coal combustion techniques: Bed combustion and suspension combustion. According to the former technique, coal is fed onto a fire grate and the combustion type depends on the directions of flow of the fuel and of the air. This type of combustion takes place in a stoker. The latter type, taking place in a fluidized bed, is a process in which suitably prepared solid particles are suspended in a uniformly distributed upward flow of the fluid. These are high efficiency devices, capable of attaining heating capacities as high as 135 tons of steam per hour [13].

Stoker furnaces are the oldest and the most commonly used devices for industrial coal bed combustion. In these devices, crushed coal (typically, $95 \%$ particles below $32 \mathrm{~mm}$ and $20 \%$ to $60 \%$ below $6 \mathrm{~mm}$ ) is fed onto the stoker where primary air flows upward through the coal bed. The crushed coal pieces are heated, dried, degassed, and combusted, leaving ash at the bottom of the bed. A layer of ash is formed, which protects the stoker from excess heat. The temperature in the coal bed depends on the rate of combustion, type and size of the coal particles, and on the coal bed thickness. Any volatile components and carbon monoxide formed during the incomplete combustion of coal are burned above the fuel bed, into which secondary air is injected to facilitate combustion. The energy requirements of the stoker furnaces are low but losses of fuel in such devices are significant [14].

In the suspension combustion technology, fine coal is thoroughly mixed with air. This takes place in pulverized-coal furnaces or in cyclone furnaces. In the pulverized-coal furnaces, the coal is taken along with the flowing air. In the cyclone furnaces, the coal particles whirl in the air flow [13].

In the pulverized-coal furnaces, the whole furnace capacity is used for the combustion of solid fuels. Coal is ground to fine particles before being mixed with air and combusted in the flue gas flow. This fuel can also be mixed with biomass or other materials [15]. This is definitely the most commonly used technique of coal combustion. It eliminates the need to use the supporting stoker and the limitations inherent in the equipment. It also enables satisfactory combustion of virtually any grade of coal [16]. Moreover, these devices release much more heat per unit volume of the boiler; therefore, they are used for generating steam in high-capacity applications, above $135 \mathrm{t} / \mathrm{h}$. Pulverized-coal furnaces can be made compatible with steam turbines of capacities ranging from 50 to $1300 \mathrm{MWe}$. They have the essential advantage of being highly reliable and adaptable to all coal grades; they are also fully automated and can be extended to form larger units. Their disadvantages include high energy consumption in the coal crushing step, and high emissions of solid particles, $\mathrm{SO}_{2}$, and NOx [17].

Cyclone furnaces are another example of a conventional combustion technology. These devices are able to handle larger coal particles $(6 \mathrm{~mm})$ in the form of suspension. Moreover, during combustion, they generate considerable amounts of heat, even as high as $20,000 \mathrm{MJ} \cdot \mathrm{hm}^{-3}$, whereas dry and wet boilers (pulverized-coal boilers) generate a maximum of 5800 and $15,600 \mathrm{MJ} \cdot \mathrm{hm}^{-3}$, respectively. Owing to centrifugal forces and the presence of molten slug on the walls, corrosion caused by volatile ash is much lower in a cyclone furnace than in other combustion systems. However, this type of combustion promotes the formation of excess $\mathrm{NO}_{\mathrm{x}}$ [18].

The fluidized-bed combustion technology is one of the essential and most recent achievements in coal combustion [19]. The technology has many uses in power engineering, metallurgy, the chemical and pharmaceutical industries, and in other industries [20]. The principal advantage of fluidized-bed combustion is that high indicators of heat exchange in the bed are obtained, which enables more compact units to be designed. This, in turn, is connected with lower investment and depreciation 
costs. Furthermore, the fluidized-bed technologies are characterized by higher combustion efficiencies, higher emissions of heat, up to $3 \mathrm{MW} / \mathrm{m}^{2}$ of the bed surface area, and the rate of corrosion affecting the furnace is lower. Since coal combustion takes place at much lower and more evenly distributed temperatures (below $1000^{\circ} \mathrm{C}$ ), $\mathrm{NO}_{\mathrm{x}}$ emissions are lower and the use of sorbents to handle sulfur in the bed enables a considerable reduction of $\mathrm{SO}_{2}$ emissions [21]. On the other hand, the technologies have certain drawbacks: Rather high amounts of solid residue (some of which require special disposal techniques), higher ash level of coal in comparison with the pulverized-coal boiler, and the formation of more $\mathrm{N}_{2} \mathrm{O}$, because of lower combustion temperatures.

A growing demand for energy generated from coal and natural gas leads to the depletion of coal reserves. As in all fossil fuels, the reproduction of coal resources is a very lengthy process. Environmental issues related to harmful emissions of the products of fossil fuel combustion are also important. That is why alternative fuels are sought. Technologies for fluidized-bed fuel combustion are also useful in the case of alternative fuels (for instance, biomass), which may cover part of the demand on fossil fuels [22].

Coal, which is the essential feedstock in the production of energy, is composed mainly of carbon, sulfur, oxygen, hydrogen, a small amount of nitrogen, and traces of heavy metals. Its combustion as fuel is a source of emissions of toxic gases [23], leading to human health effects as well as environmental issues [24]. High environmental pollution, which is generated by coal-fired power plants and boilers, is the main reason why the problem of high emissions of contaminants has for some time been addressed by researchers [25].

Since coal, including fine coal, is so widely used for energy production, many types of modifiers have been developed to help reduce the noxiousness of its combustion.

A great variety of modifiers have been designed to improve the conditions of coal combustion as fuel. A majority of these modifiers help to keep the boiler heat surfaces clean and to reduce NOx and $\mathrm{SO}_{2}$ emissions and the non-burned organic residue [26]. They are typically carried into the furnace chamber as a bulk material or emulsion. Chmielewski et al. in their research work introduced ammonia gas before the reaction chamber or, in the case of ammonia water, directly into the flue-gas wetting column [27]. In the method reported by Doggalia et al., the catalyst was introduced as a powder, with a grain size $<100 \mu \mathrm{m}[28]$.

The most widely used modifiers of solid fuel combustion are copper compounds and sodium chloride. The introduction of $\mathrm{NaCl}$ into the system has a favorable effect on the coal combustion process. A dose in the range $7-8 \mathrm{~g} \mathrm{NaCl} / \mathrm{m}^{2}$ of the furnace area is found to be optimum. The modifier was found to improve the heating capacity and reduce the environmental emissions of CO and NOx. In addition, it helped to decrease the air excess factor (related to the air supplied into the combustion chamber) and to reduce the flue-gas heat losses by approximately $12 \%$ [29]. In the conditions prevailing in the combustion chamber, sodium chloride is partly decomposed into hydrogen chloride and sodium oxide. Hydrogen chloride reacts with oxides in the solid residue, leading to the formation of metal chlorides, which are easily removed from the system in comparison with sintered oxides. The use of ammonium chloride will protect the heating system against low- and high-temperature corrosion. On the other hand, $\mathrm{NH}_{4} \mathrm{Cl}$ is a source of chlorine in the synthesis of toxic pollutants, including dioxins. Sui et al. studied the effect of $\mathrm{NaCl}$ and $\mathrm{Na}_{2} \mathrm{CO}_{3}$ on the emissions of particulate matter and $\mathrm{NOx}$ during coal combustion [30]. Their results indicate the superiority of $\mathrm{Na}_{2} \mathrm{CO}_{3}$ as a modifier based on the fact that it reduced the emission of both $\mathrm{NOx}$ and particulate matter.

Liu et al. [31] studied the impact of $\mathrm{NaCl}, \mathrm{CaCl}_{2}, \mathrm{FeCl}_{3}, \mathrm{FeCl}_{2}$, and $\mathrm{Fe}_{2} \mathrm{O}_{3}$ on $\mathrm{SO}_{2}$ reduction in the combustion of coal, with a grain size $<100 \mu \mathrm{m}$. Their dosage was $6 \%$ by the weight of coal. The studies indicate that $\mathrm{SO}_{2}$ emission was $32 \%$ lower after addition of $\mathrm{CaCl}_{2}$ and $14 \%$ to $18 \%$ lower (depending on the combustion rate) after the addition of $\mathrm{NaCl}$.

Yu et al. studied the influence of organic and inorganic modifiers on the combustion of three coal types: Long flame, bituminous, and anthracite. The authors used three types of modifiers, an ammonia-free gel composed of sodium silicate and a self-made protonic acid coagulant, $\mathrm{MgCl}_{2}$, 
and an antioxidant, and found out that $\mathrm{MgCl}_{2}$ had a better inhibitory effect on coal oxidation in the early stages than in the later stages of the process. In the case of the antioxidant, inhibition was better in the later stages of oxidation. In contrast to the above, the ammonia-free gel was observed to have an excellent inhibitory effect on the whole process of coal oxidation [32].

Coal is and will continue to be the principal raw material in energy production in the predictable future in Poland. Therefore, an attempt was made to improve its combustion. The present work shows the results of fine-coal combustion tests, carried out in the presence of various modifiers based on compounds comprising copper and metals from Groups I and II of the periodic table. The additives were selected on the basis of the available literature and the results of our studies on the impact of monomodifiers containing individual salts of $\mathrm{Cu}, \mathrm{Na}, \mathrm{Mg}$, and $\mathrm{NH}_{4}{ }^{+}$on coal combustion as fuel [33]. The present paper shows the results of studies on the impact of a mixture of these salts as well as Ca salts and ammonia on the combustion of fine coal. The technique by which the modifiers were introduced into the solid fuel flow was also an important aspect of the studies. The authors used their proprietary application system combining exact modifier doses with the varying fuel flow before feeding it into the test boiler.

\section{Materials and Methods}

\subsection{Materials}

Long-flame type IIA fine coal was used in the combustion tests. Its physico-chemical parameters are shown in Table 1.

Table 1. Physico-chemical parameters of fine coal.

\begin{tabular}{ccc}
\hline Parameter & Unit & Value \\
\hline Calorific value & $\mathrm{MJ} / \mathrm{kg}$ & 22.6 \\
Grain size & $\mathrm{mm}$ & $0-20$ \\
Ash content, $\mathrm{Ar}$ & $\%$ & 10.3 \\
Sulfur content, $\mathrm{Sr}$ & $\%$ & 1.2 \\
Moisture content, $\mathrm{Wr}$ & $\%$ & Maximum 25 \\
\hline
\end{tabular}

Prior to the tests, the fuel was homogenized, and representative samples were taken for elemental analysis and commercial chemical analysis.

Samples of the modifiers were prepared using the salts: $\mathrm{CuSO}_{4} \cdot 2 \mathrm{H}_{2} \mathrm{O}, \mathrm{NaCl}, \mathrm{NH}_{4} \mathrm{Cl}, \mathrm{MgSO}_{4} \cdot 7 \mathrm{H}_{2} \mathrm{O}$, $\mathrm{CaCl}_{2}$, and urea. The fine-coal combustion modifier was an aqueous solution containing $25 \% \mathrm{~m} / \mathrm{m}$ of salt [34].

\subsection{Equipment and Methodology}

The testing stand, in these studies on the impact of modifiers on fine-coal combustion, consisted of a 12-kW boiler (Model EKR-12, Simar, Pleszew, Poland) and a boiler testing system. A diagram of the coal boiler test system is shown in Figure 1.

The essential components of the test system are: Boiler with fuel bunker, a $1000-\mathrm{dm}^{3}$ buffer, circulation pump, fuel tank, modifier application system, a set of heat exchangers with coolers which dissipate energy out of the structure, and analyzers handling $\mathrm{CO}, \mathrm{CO}_{2}, \mathrm{SO}_{2}, \mathrm{NO}_{\mathrm{x}}$, and TOC. The boiler was equipped with a rotary-grate retort furnace, an aeration system based on a $0.8-\mathrm{kW}$ fan, and air ducts, which were part of the fuel feeding system. It was also provided with an automatic fuel feeder, adapted to handling fine coal.

The modifier was introduced into the fuel flow using a dedicated application system. Its design enables the preparation of a fuel-modifier mix at exact ratios, according to Formula (1):

$$
\dot{m}_{P K}=\dot{m}_{P}+\dot{m}_{K}
$$


where $\dot{m}_{P K}$ is the fuel-modifier mass flow, $\dot{m}_{P}$ is the fuel mass flow, and $\dot{m}_{K}$ is the modifier mass flow as a function of the fuel mass flow and parameters that are specific to a given type of modifier.

The emissions and concentrations of gaseous pollutants in the flue gas were measured by means of Photon gaz (Madur, Zgierz, Poland) and Ultramat U23 (Siemens, Karlsruhe, Germany) analyzers with online monitoring of $\mathrm{CO}, \mathrm{CO}_{2}, \mathrm{SO}_{2}$, and $\mathrm{NO}_{\mathrm{x}}$ levels. Total organic carbon (TOC) in the flue gas was measured using a OVF-3000 analyzer (J.U.M. Engineering, Karlsfeld, Germany). The flue-gas dust levels were measured gravimetrically, using an assembly drawing the test samples isokinetically from the flue gas.

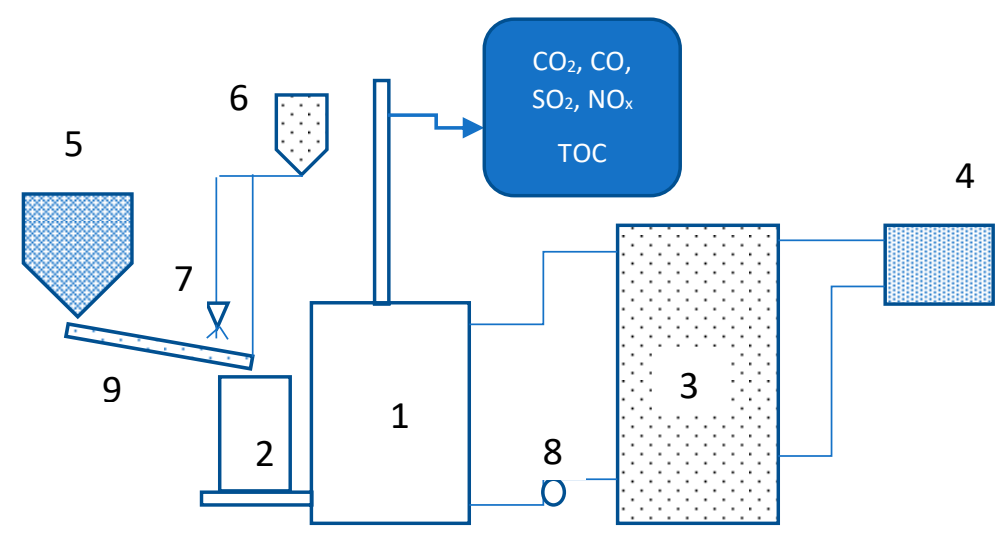

Figure 1. Coal-fired boiler test system. 1-boiler, 2-fuel bunker, 3-water tank, 4-air heater, 5-fuel tank, 6-modifier tank, 7-spraying nozzle, 8-circulating pump, 9-transporter.

During the tests, the fine-coal samples with or without the modifiers were added into the boiler after spraying them with an aqueous solution of the modifier. The modifier concentrations in the test samples were between 100 and 350 ppm in terms of metal cation and ammonium cation.

The fine-coal combustion tests were started with the test samples containing no modifier. The test results were compared with those obtained in the combustion tests carried out with the modifiers. The measurements were based on constant fuel consumption and constant air supply for the combustion process. The fuel combustion tests were carried out with or without the modifiers. The fuel samples were fed into the boiler bunker using a transporter. In the tests with the modifier, the fuel was sprayed with the modifier on its way into the bunker; the modifier level corresponded to the assumed metal concentration ranging from 100 to $350 \mathrm{ppm}$. The boiler operating parameters were as follows: Temperature of feed water was $78 \pm 0.2{ }^{\circ} \mathrm{C}$, temperature of return water was $72 \pm 0.2{ }^{\circ} \mathrm{C}$, flow rate of the water was $1.205 \pm 0.003 \mathrm{~m}^{3} / \mathrm{h}$, and the air excess factor was 3 .

The combustion tests were carried out in accordance with the requirements for boiler efficiency tests, as stated in the standard [35]. The essential flue-gas parameters, which were monitored during the measurements, included: Temperature, static pressure in the chimney, and the concentrations of oxygen and pollutants (dust and gases), specifically $\mathrm{CO}$, sulfur dioxide, and nitrogen oxides (NO and $\mathrm{NO}_{2}$ ). The total organic carbon level (TOC) in the flue gas was found using a JUM Engineering analyzer, model OVF-3000, with a continuous flame-ionization detector (FID), capable of handling volatile organic compounds. The fuel combustion efficiency was assessed directly from the balance of Formula (2):

$$
\eta_{k}=100-\sum_{i} S_{i}
$$

Relative heat losses, $S_{i}$, are defined as the ratio of the absolute heat loss, $Q_{i}$, in $\mathrm{kJ} / \mathrm{kg}$ of fuel and the calorific value of the fuel, $W_{u}$, in $\mathrm{kJ} / \mathrm{kg}$ of fuel (Formula (3)):

$$
S_{i}=\frac{Q_{i}}{W_{u}} \cdot 100
$$


The fine-coal combustion test samples were assigned the following symbols: M0—no modifier; $\mathrm{M} 1, \mathrm{M} 2, \mathrm{M} 3$, and $\mathrm{M} 4-$ modifier containing $\mathrm{Cu}, \mathrm{Na}, \mathrm{Mg}$, and $\mathrm{NH}_{4}{ }^{+}$in the amounts of 100, 200, 250, and 350 ppm, respectively; $\mathrm{M} 5$ and $\mathrm{M} 6$ - modifier containing $\mathrm{Cu}, \mathrm{Na}, \mathrm{Mg}, \mathrm{NH}_{4}{ }^{+}$, and $\mathrm{Ca}$ in the amounts of 250 and 350 ppm, respectively; $\mathrm{M} 7$-modifier containing $\mathrm{Cu}, \mathrm{Na}, \mathrm{Mg}$, and $\mathrm{NH}_{4}{ }^{+}$in the amount of 350 ppm and urea; and M8-modifier containing $\mathrm{Cu}, \mathrm{Na}, \mathrm{Mg}, \mathrm{NH}_{4}{ }^{+}$, and $\mathrm{Ca}$ in the amount of 350 ppm and urea.

An analysis of the efficiency of the use of modifiers of solid fuels in boilers operated in power plants is also provided in this paper. It was calculated using the following formula (Formula (4)):

$$
\mathrm{OP}=((\mathrm{IW}-\mathrm{OK}) \times \mathrm{MS}+\mathrm{OK}) \times \mathrm{CT},
$$

wherein:

$\mathrm{OP}=$ total fuel savings, USD;

IW = combustion of coal with the catalyst, tons;

MS = savings resulting from the use of a control and supervision system, \%;

$\mathrm{OK}=$ coal savings on catalyst (IW*PS), tons;

PS = fuel savings due to the catalyst, $\%$; and

$\mathrm{CT}=$ cost of 1 ton of coal, USD.

The savings resulting from the use of the control and supervision system were calculated based on the number of tons of coal, corrected for the efficiency attributed to the catalyst. The result is the saved number of tons, multiplied by the price of 1 ton.

\section{Introduction of the Modifiers into the Fine Coal Flow}

The application of modifiers in solid-fuel combustion is a commonly used practice in power engineering both in Poland and in other countries. A variety of modifiers are introduced into the fuel to improve its combustion conditions by keeping the heat exchange surfaces clean and reducing the emissions of $\mathrm{NOx}$ and $\mathrm{SO}_{2}$, soot, and $\mathrm{CO}$.

Instrumentation solutions, enabling the exact dosage of modifiers into the fuel mix entering the combustion chamber, are an essential component of the modifier application systems used with solid fuels. They are also useful in assessing measurable energy results for use in settling accounts with potential consumers. The automated dosage system enables the modifier to be added at controlled flow rates, depending on that of the fuel mix and on the expected fuel modifier level, Figure 2.

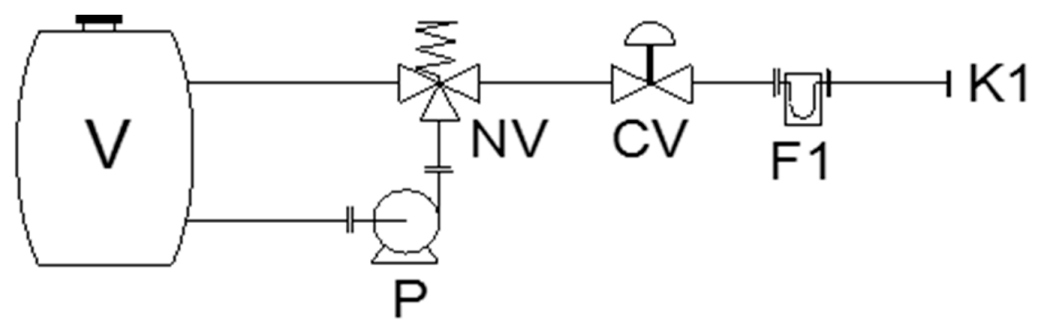

Figure 2. Modifier dosage into the coal fuel (V-modifier solution tank, p-pump, F-flow meter, NV and $\mathrm{CV}$-valves, $\mathrm{K} 1$ - connection to the fuel dosage system).

For a higher dosage precision, the modifiers were used in the form of aqueous solutions, which are more easily applied by spraying them onto the fuel before it is fed into the boiler. The concentration of active modifier components was selected so as to keep the consumption of the aqueous solution in the range $2-3 \mathrm{dm}^{3}$ per $1 \mathrm{Mg}$ of coal.

The obtained ecological and energy results of the use of modifiers were assessed using the existing instrumentation infrastructure and temporary instruments installed on the boiler for the duration 
of the tests. The modifier dosage system can be controlled using a computer with storage of the measurement data.

The advantages of modifiers in coal combustion as fuel are connected with the invariably high boiler efficiency, its extended operation, and reduced maintenance costs. Owing to reduced levels of hydrocarbons in the off gas and lower amounts of residue in the combustion chamber, the fuel combustion is more efficient and the deposition of non-combusted particles in the combustion chamber is prevented. The overall results include improved boiler efficiency, reduced emissions of harmful gases into the atmosphere, and a lower corrosive effect of flue gas.

The economic result of the use of modifiers is related to the higher amount of heat being obtained per mass unit of fuel, improved boiler performance, reduced maintenance costs, and lower environmental fees.

Accounts with consumers will be settled in an innovative way; this is an important issue in the commercial implementation of the system. The modifiers will be supplied to the consumers at cost to the manufacturers. Payment for the application of the system will constitute $20 \%$ to $30 \%$ of the calculated results of fuel combustion. This will help minimize the risk taken by energy producers and the company implementing the fuel combustion efficiency system will seem to be more credible.

\section{Results and Discussion}

The fine-coal combustion test results were carried out on samples with either no modifier or with a modifier comprising $\mathrm{Cu}, \mathrm{Na}, \mathrm{Mg}$, and $\mathrm{NH}_{4}{ }^{+}$. In [33], these authors described the impact of monometallic modifiers comprising the salts of $\mathrm{Cu}, \mathrm{Na}, \mathrm{Mg}$, or $\mathrm{NH}_{4}{ }^{+}$on the combustion of coal (eco-pea) as fuel. The results reported therein show the impact of the respective monometallic modifiers on the atmospheric emissions of harmful compounds. The modifiers used in the fine-coal combustion tests as described in this paper were polymetallic modifiers comprising a mixture of the above-mentioned salts as well as extra components, Ca salts and urea.

Figures 3 and 4 show the results of the flue-gas analysis and the value of boiler efficiency determined in the fine-coal combustion tests with the polymetallic modifier comprising a mixture of metal compounds, at the following concentrations: 100, 200, 250, and $350 \mathrm{ppm}$.

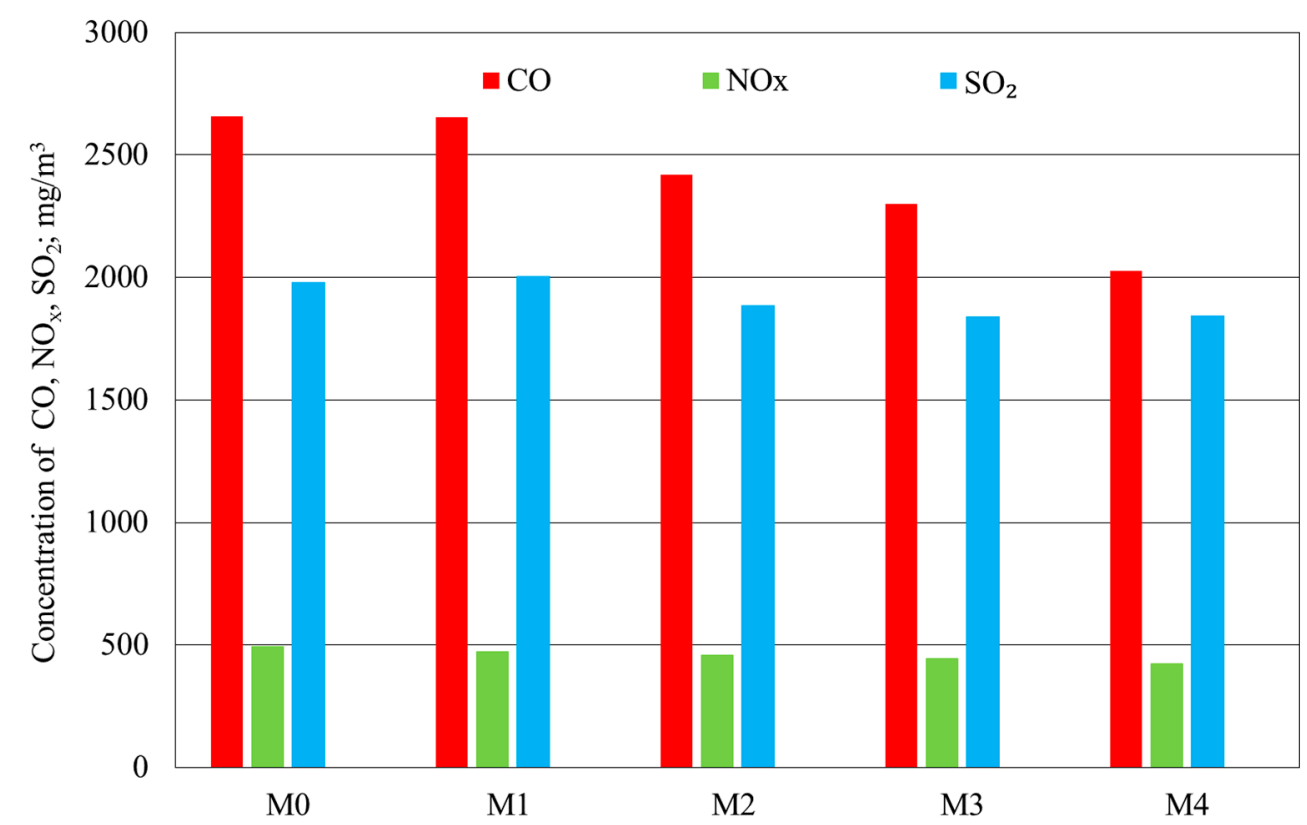

Figure 3. Results of the determination of $\mathrm{CO}, \mathrm{NO}_{\mathrm{x}}$, and $\mathrm{SO}_{2}$ levels in fine-coal combustion tests: M0—no modifier; M1-modifier concentration 100 ppm, M2-200 ppm, M3-250 ppm, M4-350 ppm. 


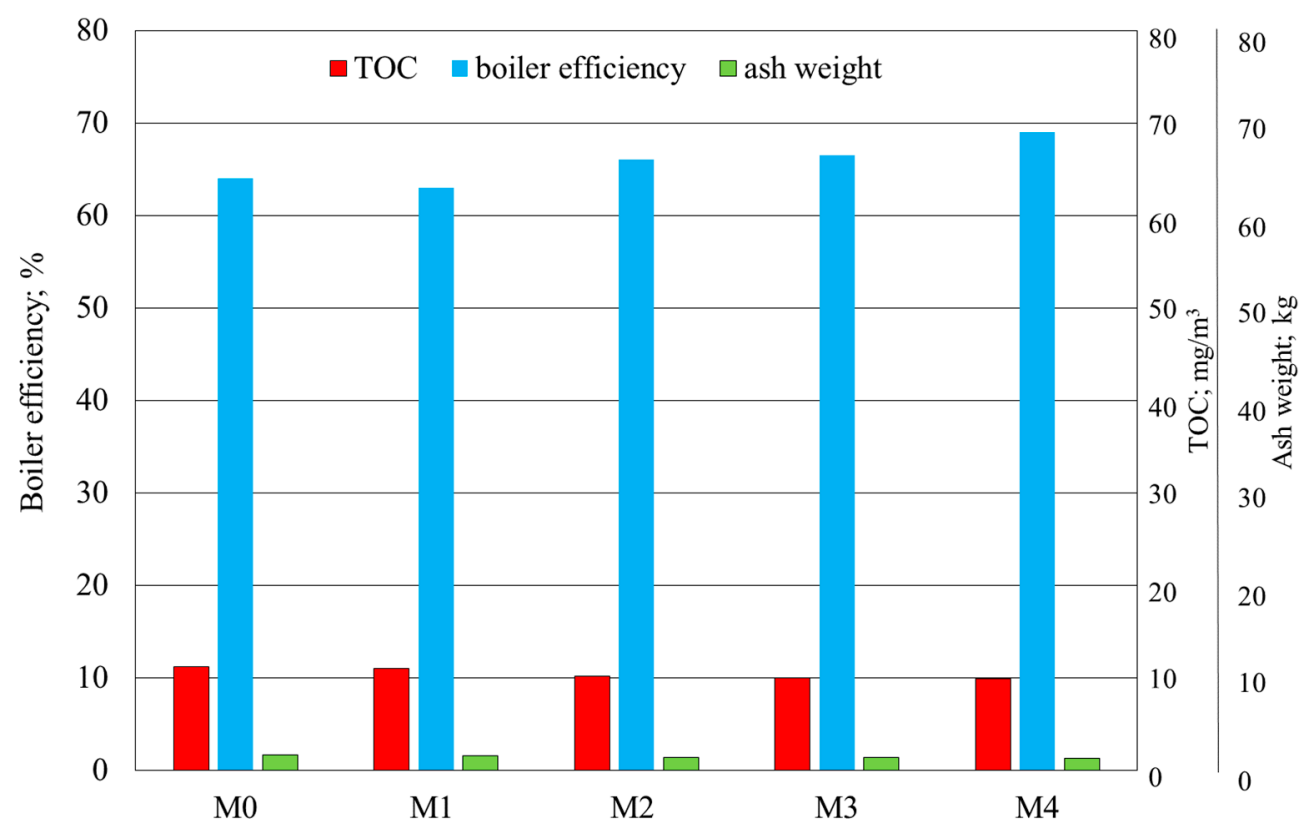

Figure 4. Results of the determination of TOC, boiler efficiency and ash weight in fine-coal combustion tests: M0—no modifier; M1—modifier concentration 100 ppm, M2-200 ppm, M3-250 ppm, M4-350 ppm.

Averaged results of the measurements of pollutant concentrations in the various measurement series (in combustions tests with or without a modifier) were converted to $\mathrm{mg} / \mathrm{m}^{3}$ for a fuel-gas oxygen level of $10 \%$. Based on these, a percentage change in concentration, resulting from the use of the fuel with or without a modifier, was obtained for the various pollutants.

The modifier containing $\mathrm{Cu}, \mathrm{Na}, \mathrm{Mg}$, and $\mathrm{NH}_{4}{ }^{+}$in the amount of $100 \mathrm{ppm}$ demonstrated a rather low activity, only slightly reducing $\mathrm{CO}$ and NOx emissions in the flue gas. The TOC level in the flue gas was slightly lower and the ash weight was also determined. On the other hand, the flue-gas $\mathrm{SO}_{2}$ level was slightly higher, in comparison with the test sample with no modifier.

An explicit impact of the modifier, reducing $\mathrm{CO}$ and $\mathrm{SO}_{2}$ emissions, was observed starting from the concentration of $200 \mathrm{ppm}$. The highest activities were observed for the modifier concentrations of 250 and $350 \mathrm{ppm}$. The levels of the components of interest in the flue gas decreased with increasing modifier concentrations, and the highest activity was observed for the modifier used at a concentration of $350 \mathrm{ppm}$. In this case, the boiler efficiency, as measured by the direct method, was high. Only the level of $\mathrm{SO}_{2}$ was similar to that for sample M3, in which the modifier's concentration was $250 \mathrm{ppm}$.

Representative results of measurements of the content of oxygen, carbon dioxide, and carbon(II) oxide for a sample with M3 are shown in Figure 5. The dotted lines denote the exact moments when the fuel-modifier mix was fed to the boiler. A marked drop in oxygen levels from ab. $13 \%$ to ab. $11 \%$ was noted and was accompanied by an increase in the concentration of carbon dioxide. In the specific conditions of the combustion test, the addition of a modifier also resulted in lower levels of carbon(II) oxide in the flue gas, which is to be interpreted as lower losses on incomplete combustion.

The results of these measurements reflect the various stages of the test combustion process. This is especially clear in the case of $\mathrm{CO}$, for which the following stages can be seen: Lighting, stabilization of combustion in the boiler using a fuel without a modifier (a clearly higher value of average CO levels), burning of fuel with a modifier (lower value of average $\mathrm{CO}$ level), and the stage of burnup and burnout of the boiler with the fuel without a modifier (again, higher average CO level). 


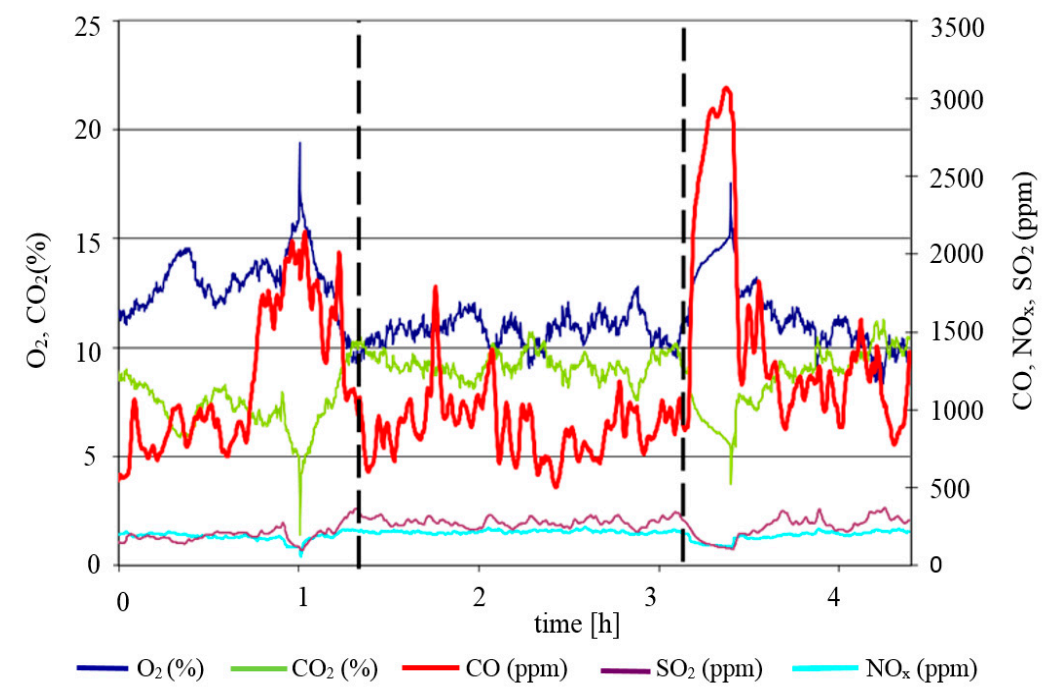

Figure 5. Results of measurement of $\mathrm{O}_{2}, \mathrm{CO}_{2}, \mathrm{CO}, \mathrm{NO}_{\mathrm{x}}$, and $\mathrm{SO}_{2}$ in the combustion of coal as fuel with the addition of M3 modifier.

Measurements of TOC in the flue gas (Figure 6) were conducted at the same time. It was observed that the TOC level was reduced during the combustion of the fuel with the modifier, and the process running with or without a modifier also comprised well-defined stages.

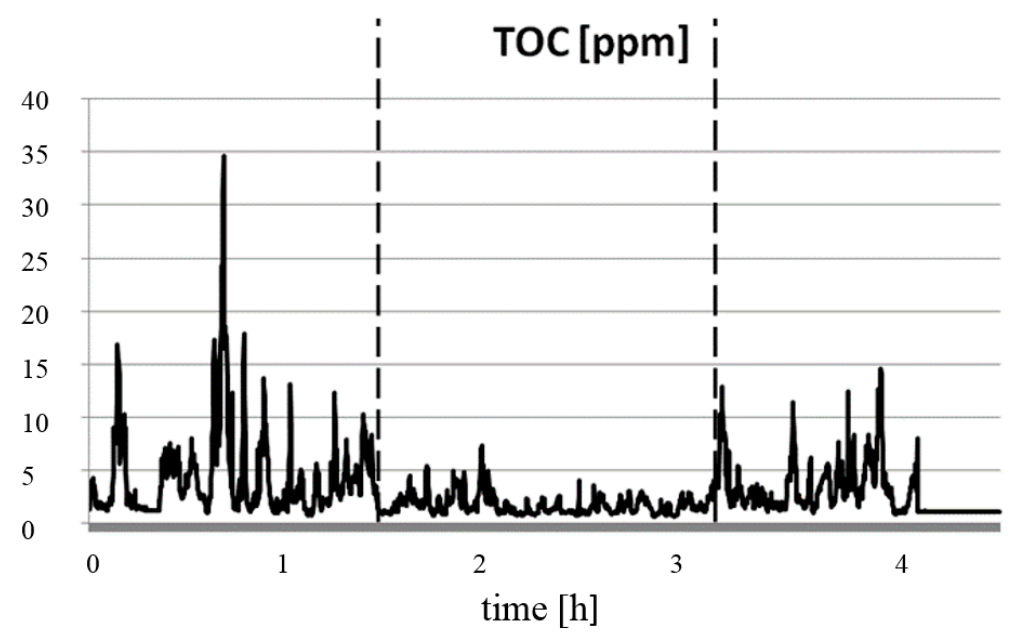

Figure 6. Results of the determination of total organic carbon (TOC) in the combustion of fine coal with M3 modifier.

The results of the fine-coal combustion tests with or without the $\mathrm{Cu}, \mathrm{Na}, \mathrm{Mg}$ and $\mathrm{NH}_{4}{ }^{+}$modifier and with the modifier with the addition of $\mathrm{Ca}$ at a concentration of $250 \mathrm{ppm}$ are shown in Figures 7 and 8 .

Addition of Ca into the modifier (sample M5) was found to have an undesirable effect on $\mathrm{CO}, \mathrm{NO}_{\mathrm{x}}$ emissions in comparison with M2. On the other hand, these emissions were lower than those for sample $\mathrm{M} 0$ without the modifier. Ca was found to reduce the flue-gas level of $\mathrm{SO}_{2}$. The advantages of reducing $\mathrm{SO}_{2}$ levels in the combustion tests carried out on coal, with a grain size $<100 \mu \mathrm{m}$, was described by Liu et al. in [31]. According to those authors, $\mathrm{SO}_{2}$ emissions were reduced by as much as $32 \%$ after the addition of $\mathrm{CaCl}_{2}$ and by $14 \%$ to $18 \%$ (for various combustion rates) after the addition of $\mathrm{NaCl}$. In that case, an additive comprising $\mathrm{NaCl}, \mathrm{CaCl}_{2}, \mathrm{FeCl}_{3}, \mathrm{FeCl}_{2}$, and $\mathrm{Fe}_{2} \mathrm{O}_{3}$ was added into the fuel in the amount of $6 \%$ of the coal feed, which was much more than the level used by these authors in their own tests. 


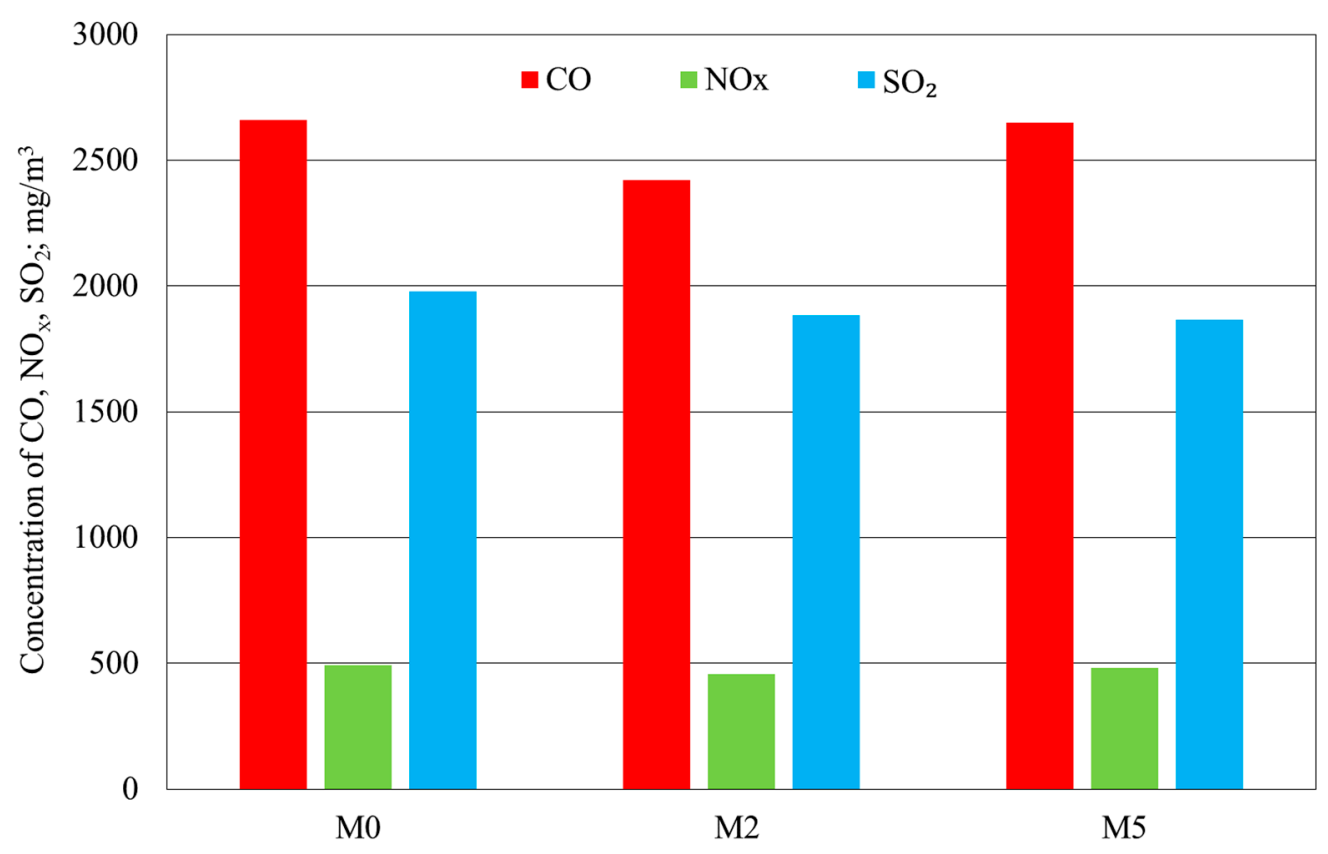

Figure 7. Results of the determination of $\mathrm{CO}, \mathrm{NOx}$, and $\mathrm{SO}_{2}$ levels in fine-coal combustion tests at a modifier concentration of 250 ppm: M0-no modifier; $\mathrm{M} 2$ - modifier with $\mathrm{Cu}, \mathrm{Na}, \mathrm{Mg}$ and $\mathrm{NH}_{4}{ }^{+}$; M5-modifier with $\mathrm{Cu}, \mathrm{Na}, \mathrm{Mg}, \mathrm{NH}_{4}{ }^{+}$, and $\mathrm{Ca}$.

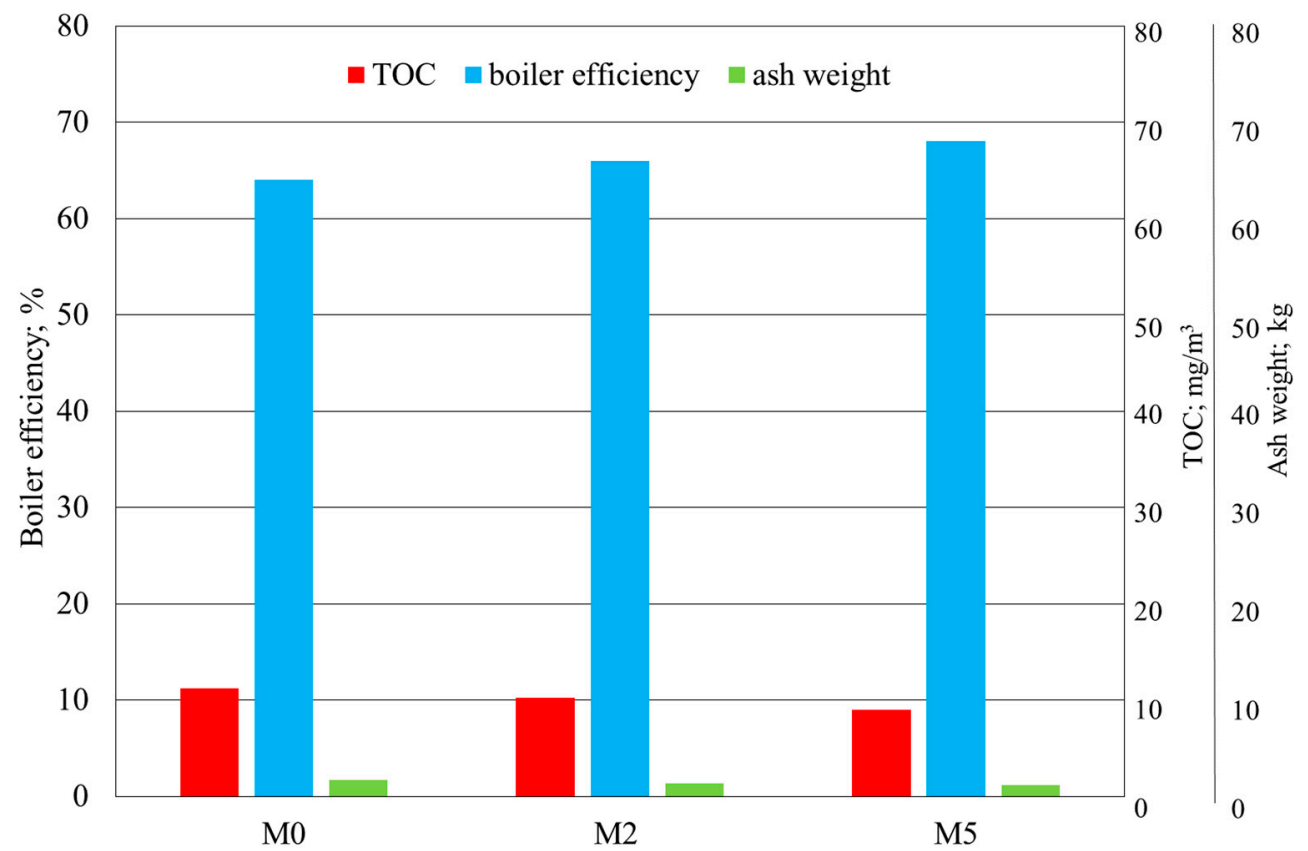

Figure 8. Results of the determination of TOC, boiler efficiency, and ash weight in fine-coal combustion tests at a modifier concentration of 250 ppm: M0-no modifier; $\mathrm{M} 2$-modifier with $\mathrm{Cu}, \mathrm{Na}, \mathrm{Mg}$, and $\mathrm{NH}_{4}{ }^{+}$; M5-modifier with $\mathrm{Cu}, \mathrm{Na}, \mathrm{Mg}, \mathrm{NH}_{4}{ }^{+}$, and Ca.

In addition, higher boiler efficiency, lower TOC levels in the flue gas, and lower ash weights than those for M0 and M2 were obtained.

Figures 9 and 10 show the results of the fine-coal combustion tests without a modifier and with the M4 modifier as compared with those of the tests with modifiers with added Ca or urea or Ca plus urea at the modifier concentration of $350 \mathrm{ppm}$. 


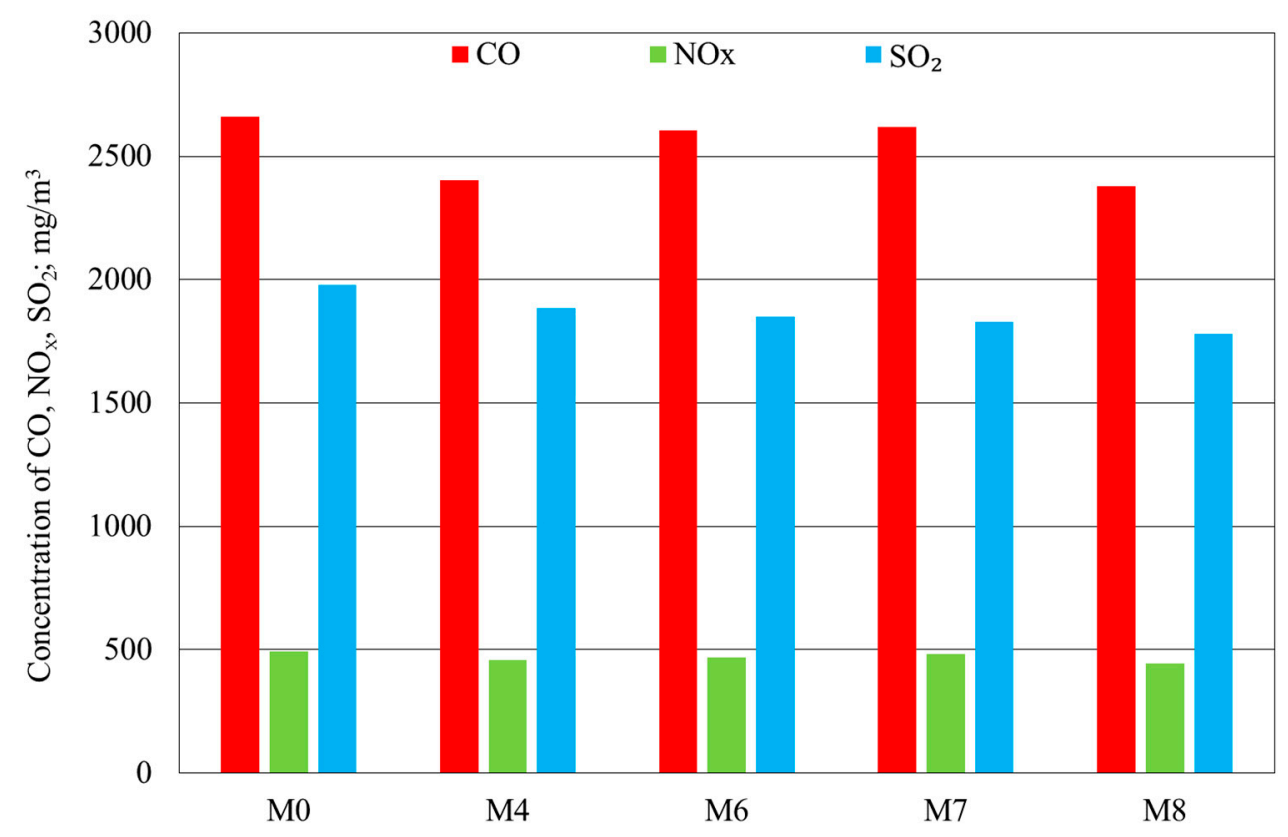

Figure 9. Results of the determination of $\mathrm{CO}, \mathrm{NOx}$, and $\mathrm{SO}_{2}$ levels in fine-coal combustion tests at a modifier concentration of 350 ppm: M0-no modifier; $\mathrm{M} 4$-modifier $\mathrm{Cu}, \mathrm{Na}, \mathrm{Mg}$, and $\mathrm{NH}_{4}{ }^{+}$; M6-modifier with $\mathrm{Cu}, \mathrm{Na}, \mathrm{Mg}, \mathrm{NH}_{4}{ }^{+}$, and $\mathrm{Ca}$; $\mathrm{M} 7$ - modifier with $\mathrm{Cu}, \mathrm{Na}, \mathrm{Mg}, \mathrm{NH}_{4}{ }^{+}$, and urea; M8-modifier with $\mathrm{Cu}, \mathrm{Na}, \mathrm{Mg}, \mathrm{NH}_{4}{ }^{+}, \mathrm{Ca}$, and urea.

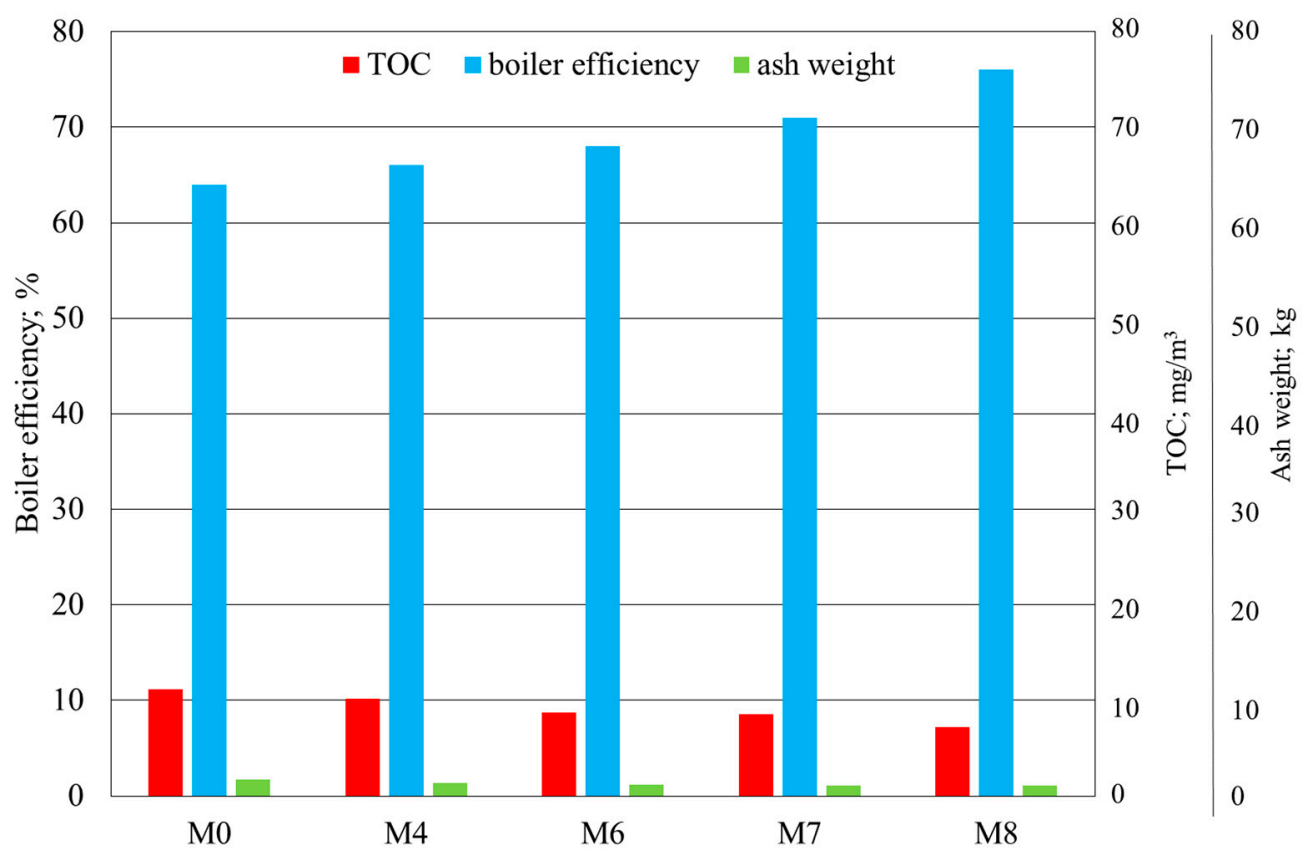

Figure 10. Results of the determination of TOC, boiler efficiency, and ash weight in fine-coal combustion tests at a modifier concentration of $350 \mathrm{ppm}$ : M0—no modifier; $\mathrm{M} 4$ - modifier with $\mathrm{Cu}, \mathrm{Na}, \mathrm{Mg}$, and $\mathrm{NH}_{4}{ }^{+}$; M6-modifier with $\mathrm{Cu}, \mathrm{Na}, \mathrm{Mg}, \mathrm{NH}_{4}{ }^{+}$, and $\mathrm{Ca}$; $\mathrm{M} 7$ - modifier with $\mathrm{Cu}, \mathrm{Na}, \mathrm{Mg}, \mathrm{NH}_{4}{ }^{+}$, and urea; $\mathrm{M} 8$ - modifier with $\mathrm{Cu}, \mathrm{Na}, \mathrm{Mg}, \mathrm{NH}_{4}{ }^{+}, \mathrm{Ca}$, and urea.

The results of fine-coal combustion tests, carried out using $350 \mathrm{ppm}$ of the M4 modifier, confirm the advantages of increasing the concentrations of a modifier comprising $\mathrm{Cu}, \mathrm{Na}, \mathrm{Mg}$, and $\mathrm{NH}_{4}{ }^{+}$on the reduction of harmful emissions of combustion products, as shown in Figure 3. As in the combustion test with 250 ppm, the introduction of calcium into the M4 modifier (sample M6) led to higher flue-gas 
levels of $\mathrm{CO}$ and a slight decrease in the concentration of $\mathrm{SO}_{2}$, compared with the combustion tests with or without the M4 modifier.

In the sample where Ca was replaced with urea (M7), the flue-gas level of $\mathrm{CO}$ was higher than that for the M4 sample (Figure 9). In that case, the addition of urea, regarded as an extra source of ammonia, led to higher flue-gas levels of $\mathrm{CO}$. The obtained results are similar to those reported by Yu et al. in [32]: The authors found that the addition of ammonia resulted in higher flue-gas levels of $\mathrm{NO}_{\mathrm{x}}$. A similar effect of the addition of ammonia on coal combustion was described by Fan et al. in [36]. They demonstrated that, when injected into coal dust, ammonia was able to reduce $\mathrm{NO}_{\mathrm{x}}$ levels, although this took place only at extremely low oxygen levels. A particularly desirable impact on the combustion of fine coal was observed for the M8 modifier, comprising both Ca and urea.

The ash level of organic carbon in the samples with the modifiers was reduced. As a result, the amount of ash was much lower than that for the M0 sample with no modifier (Figure 10). The modifier also had a desirable effect on the boiler efficiency. The addition of calcium and urea into the M4 modifier, resulting in M6 and M7, respectively, was found both to improve the boiler efficiency and to reduce the amount of ash and the TOC percentage of ash. Particularly desirable results were obtained in the sample M8: The boiler efficiency was as high as $76 \%$; that is, some $11 \%$ more than that in M0 with no modifier, and $9 \%$ more than that in M4.

The consumption of coal for heating purposes in all facilities in Poland is estimated to be 25 to 30 million ton/year. Energy efficiency figures for different system capacities are shown in Table 2. The use of solid-fuel modifiers is cost effective only in heating plants and CHP plants with capacities above $2 \mathrm{MW}$. Below that capacity, the modifier installation may be too expensive to guarantee a good enough return on the investment. It is assumed that, in addition to the modifier, a control and supervision system will be implemented for energy efficiency calculations. Its role is to improve the performance of energy generation and distribution. Assuming that savings due to the use of the catalyst are approximately $2 \%$ to $6 \%$ (depending on capacity) and those due to modernization are in the range $2 \%-8 \%$, return on investment is expected to be reached after 3 years for big boiler systems and up to 5 years for smaller ones.

Table 2. Calculation of cost efficiency.

\begin{tabular}{|c|c|c|c|c|c|c|c|}
\hline $\begin{array}{l}\text { Average } \\
\text { System } \\
\text { Capacity, } \\
\text { MW }\end{array}$ & $\begin{array}{l}\text { Coal } \\
\text { Consumption } \\
\text { per Year, Ton } \\
\text { (IW) }\end{array}$ & $\begin{array}{l}\text { Average Price } \\
\text { of Coal per } \\
\text { Ton, USD * } \\
\text { (CT) }\end{array}$ & $\begin{array}{l}\text { Cost of } \\
\text { Fuel per } \\
\text { Year, USD }\end{array}$ & $\begin{array}{l}\text { Fuel Savings } \\
\text { Due to the } \\
\text { Catalyst, \% } \\
\text { (PS) }\end{array}$ & $\begin{array}{l}\text { Fuel Savings } \\
\text { Due to } \\
\text { Modernization, } \\
\% \text { (MS) }\end{array}$ & $\begin{array}{c}\text { Economic } \\
\text { Effect, } \\
\text { USD (OP) }\end{array}$ & Result, \% \\
\hline $3 \mathrm{MW}$ & 1428.57 & 120 & 171,420 & 6.00 & $8.00 \%$ & $23,17610,285$ & 13.52 \\
\hline $10 \mathrm{MW}$ & 4347.83 & 115 & $500,000.45$ & 5.00 & $6.00 \%$ & 53,500 & 10.70 \\
\hline $30 \mathrm{MW}$ & $11,640.80$ & 100 & $1,164,080$ & 4.00 & $4.00 \%$ & $91,263.87$ & 7.84 \\
\hline $70 \mathrm{MW}$ & $26,203.21$ & 95 & $2,489,304.95$ & 3.00 & $3.00 \%$ & $141,117.92$ & 5.91 \\
\hline $100 \mathrm{MW}$ & $36,157.02$ & 90 & $3,254,131.80$ & 2.00 & $2.00 \%$ & $128,863.62$ & 3.96 \\
\hline
\end{tabular}

All ROI periods depend directly on the cost of the modifier installation and modifier type as well as on the technical condition of the boiler system and the cost of its modernization.

The benefits of the use of the catalyst are assessed based on the cost of 1 ton of coal, fuel savings due to the use of the catalyst ('Fuel savings due to the catalyst' in Table 2), and due to modernization. It is assumed that, in addition to the modifier itself, a control and supervision system will be used, which will provide a higher performance for energy generation and distribution ('Fuel savings fuel due to modernization'). The figures in the 'result' column show the ratio of the 'economic effect' and the starting amount of the fuel fired in the system ('cost of fuel per year, USD').

In addition to energy efficiency, the use of the modifier also results in about $20 \%$ lower maintenance costs. This is related, among other things, to the formation of less deposits and keeping the system in a generally better condition. 


\section{Conclusions}

The combustion of coal-based fuels is a source of environmental emissions. These emissions of pollutants can be reduced by means of modifiers, which are introduced directly into the fuel. In this research work, the effect of modifiers, comprising the salts $\mathrm{CuSO}_{4} \cdot 2 \mathrm{H}_{2} \mathrm{O}, \mathrm{NaCl}, \mathrm{NH}_{4} \mathrm{Cl}, \mathrm{MgSO}_{4} \cdot 7 \mathrm{H}_{2} \mathrm{O}$, $\mathrm{CaCl}_{2}$, and urea at various concentrations, on the combustion of fine coal was investigated. In the fine-coal combustion tests, the modifiers were observed to have a desirable effect: Both $\mathrm{CO}$ and NOx levels in the flue gas were reduced. The modifier $\mathrm{M} 4$ at $250 \mathrm{ppm}$ consisting of $\mathrm{Cu}, \mathrm{Na}, \mathrm{Mg}$, and $\mathrm{NH}_{4}{ }^{+}$ was particularly active in reducing the $\mathrm{CO}$ and $\mathrm{NO}_{\mathrm{x}}$ levels. In this case, the minimum flue-gas level of TOC and the maximum boiler efficiency were also determined for the tests, carried out with no calcium and no urea. In addition, it was observed that after the addition of $\mathrm{Ca}$ and urea to the modifier, the boiler efficiency was even better.

It was observed that the higher the modifier concentrations in the fuel, the lower the pollutant emissions. Also, the flue-gas levels of ash and TOC were observed to decrease, resulting in better boiler efficiencies. A particularly high activity was observed for the modifier used at $350 \mathrm{ppm}$ comprising of salts of $\mathrm{Cu}, \mathrm{Na}, \mathrm{Mg}$, and $\mathrm{NH}_{4}$. After adding the Ca salt modifier and urea as extra components, the authors observed a higher reduction of undesirable flue gas components and higher boiler efficiencies. In the fine coal combustion tests in which the above modifier was used, the flue-gas levels of $\mathrm{CO}$, $\mathrm{NO}_{x}$, and $\mathrm{SO}_{2}$ were reduced by approximately $9 \%, 12 \%$, and $10 \%$, respectively, compared with the no-modifier combustion test. In this case, the boiler efficiency increased from $65 \%$ in the no-modifier test to $76 \%$ in the tests with the modifier. The tests were carried out with the use of an application system designed by the authors: It enabled dosage of exact amounts of the modifier into a varied stream of fuel being fed into the boiler. The modifiers used in the fine coal combustion process also provided the benefit of improving the amount of heat generated per fuel unit mass, inhibiting the corrosive effect of fuel, reducing boiler maintenance costs, and extending its service life.

The use of the modifier with solid fuels is cost effective only in heat plants and CHP plants above $2 \mathrm{MW}$. In addition to the modifier itself, a control and supervision system must be used to assess cost efficiency and improve the efficiency of energy generation and distribution. Implementation of the solutions described in this paper will also help reduce boiler maintenance costs.

Author Contributions: Conceptualization, W.J.T. and J.G.-T.; methodology, W.J.T.; formal analysis, J.G.-T.; investigation, W.J.T.; resources, J.G.-T.; data curation, J.G.-T.; writing-original draft preparation, W.J.T.; writing-review and editing, J.G.-T.; visualization, J.G.-T.; supervision, W.J.T.

Funding: This work was supported by the Innovative Economy Operational Program 2007-13 (No. POIG.01.04.00-16-159/12).

Conflicts of Interest: The authors declare no conflict of interest.

\section{References}

1. Farfan, J.; Breyer, C. Structural changes of global power generation capacity towards sustainability and the risk of stranded investments supported by a sustainability indicator. J. Clean. Prod. 2017, 141, 370-384. [CrossRef]

2. Nyashina, G.S.; Strizhak, P.A. The influence of liquid plant additives on the anthropogenic gas emissions from the combustion of coal-water slurries. Environ. Pollut. 2018, 242, 31-41. [CrossRef] [PubMed]

3. Goswami, S. Impact of Coal Mining on Environment. Eur. Res. 2015, 92, 185-196.

4. Su, F.-Q.; Itakura, K.-I.; Deguchi, G.; Ohga, K. Monitoring of coal fracturing in underground coal gasification by acoustic emission techniques. Appl. Energy 2017, 189, 142-156. [CrossRef]

5. Zhao, C.; Zhang, W.; Wang, Y.; Liu, Q.; Guo, J.; Xiong, M.; Yuan, J. The economics of coal power generation in China. Energy Policy 2017, 105, 1-9. [CrossRef]

6. Teng, X.; Lu, D.; Chiu, Y. Emission reduction and energy performance improvement with different regional treatment intensity in China. Energies 2019, 12, 237. [CrossRef]

7. Hao, X.; Song, M.; Feng, Y.; Zhang, W. De-capacity policy Effect on China's Coal Industry. Energies 2019, 12, 2331. [CrossRef] 
8. Enerdata. Global Energy Statistical Yearbook. 2019. Available online: https://yearbook.enerdata.net/ totalenergy/world-consumption-statistics.html (accessed on 9 October 2019).

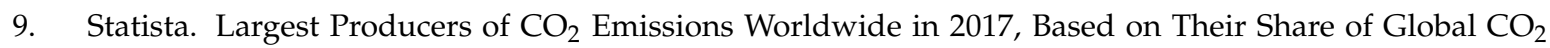
Emissions. 2017. Available online: https://www.statista.com/statistics/271748/the-largest-emitters-of-co2-inthe-world (accessed on 9 October 2019).

10. Olkuski, T.; Suwara, W.; Wyrwa, A. Perspectives of coal power technologies in Poland and the world. Rynek Energii 2017, 4, 13-17.

11. Ciesielczuk, S. Coal Mining and Waste Dumps in Poland. In Book Coal and Peat Fires: A Global Perspective; Stracher, G.B., Prakash, A., Sokol, E.V., Eds.; Elsevier: Amsterdam, The Netherlands, 2015; pp. 464-474.

12. Yu, X.; Luo, Z.; Gan, D. Desulfurization of high sulfur fine coal using a novel combined beneficiation process. Fuel 2019, 254, 115603. [CrossRef]

13. Vamvuka, D. Overview of Solid Fuels Combustion Technologies. In Handbook of Combustion: Solid Fuels; Lackner, M., Winter, F., Agarwal, A.K., Eds.; WILEY-VCH Verlag GmbH \& Co. KGaA: Weinheim, Germany, 2010; Volume 4, pp. 31-84.

14. Zhang, Q.; Yi, H.; Yu, Z.; Gao, J.; Wang, X.; Lin, H.; Shen, B. Energy-exergy analysis and energy efficiency improvement of coal-fired industrial boilers based on thermal test data. Appl. Therm. Eng. 2018, 144, 614-627. [CrossRef]

15. Park, H.Y.; Park, Y.H.; Kim, Y.J.; Kim, H.H.; Park, S.B. The interaction of woody biomass with bituminous coal in their blends. Environ. Eng. Res. 2017, 22, 320-328. [CrossRef]

16. Gurel, B.; Ipek, O.; Kan, M. Numerical Analysis of Pulverised Coal Fired Boiler with Different Burner Geometries. Acta Phys. Pol. A 2015, 128, 43-45. [CrossRef]

17. Sung, Y.; Moon, C.; Eom, S.; Gyungmin Choi, G.; Kim, D. Coal-particle size effects on NO reduction and burnout characteristics with air-staged combustion in a pulverized coal-fired furnace. Fuel 2016, 182, 558-567. [CrossRef]

18. Zarzycki, R.; Bis, Z.; Kobyłecki, R. The concept of coal burning in a cyclone furnace. Procedia Eng. 2016, 157, 472-479. [CrossRef]

19. Man, C.; Zhu, J.; Ouyang, Z.; Liu, J.; Lyu, Q. Experimental study on combustion characteristics of pulverized coal preheated in a circulating fluidized bed. Fuel Process. Technol. 2018, 172, 72-78. [CrossRef]

20. Zhang, Y.; Ran, Z.; Jin, B.; Zhang, Y.; Zhou, C.; Sher, F. Simulation of Particle Mixing and Separation in Multi-Component Fluidized Bed Using Eulerian-Eulerian Method: A Review. Int. J. Chem. React. Eng. 2019. [CrossRef]

21. Li, L.; Duan, L.; Yang, Z.; Zhao, C. Pressurized oxy-fuel combustion characteristics of single coal particle in a visualized fluidized bed combustor. Combust. Flame 2020, 211, 218-228. [CrossRef]

22. Hai, I.U.; Sher, F.; Yaqoob, A.; Liu, H. Assessment of biomass energy potential for SRC willow woodchips in a pilot scale bubbling fluidized bed gasifier. Fuel 2019, 258, 116143. [CrossRef]

23. Munawer, M.E. Human health and environmental impacts of coal combustion and post-combustion wastes. J. Sustain. Min. 2018, 17, 87-96. [CrossRef]

24. Bogomolov, A.; Valiullin, T.; Vershinina, K.; Shevyrev, S.; Shlege, N. Igniting Soaring Droplets of Promising Fuel Slurries. Energies 2019, 12, 208. [CrossRef]

25. Bascom, R.; Bromberg, P.A.; Costa, D.L.; Devlin, R.; Dockery, D.W.; Frampton, M.W. Health effects of outdoor air pollution. Am. J. Respir. Crit. 1996, 153, 477-498.

26. Centi, G.; Ciambelli, P.S.; Perathoner, S.; Russo, P. Outlooks for environmental catalysis. Catal. Today 2002, 75, 1-2. [CrossRef]

27. Chmielewski, A.; Tymiński, B.; Pawelec, A. Reaktor do oczyszczania spalin metoda radiacyjna. Przem. Chem. 2003, 82, 1013-1015.

28. Doggalia, P.; Kusabab, H.; Einagab, H.; Bensaidc, S.; Rayalua, S.; Teraokab, Y.; Lanhsetwara, N. Genotoxic endpoints in the earthworms sub-lethal assay to evaluate natural soils contaminated by metals and radionuclides. J. Hazard. Mater. 2011, 186, 796-804.

29. Prelec, Z.; Mrakovcić, T.; Dragicević, V. Performance study of fuel oil additives in real power plant operating conditions. Fuel Process. Technol. 2013, 110, 176-183. [CrossRef]

30. Sui, Z.; Zhang, Y.; Yao, J.; Norris, P.; Cao, Y.; Pan, W.-P. The influence of $\mathrm{NaCl}$ and $\mathrm{Na}_{2} \mathrm{CO}_{3}$ on fine particulate emission and size distribution during coal combustion. Fuel 2016, 184, 718-724. [CrossRef] 
31. Liu, Y.; Che, D.; $\mathrm{Xu}, \mathrm{T}$. Catalytic reduction of $\mathrm{SO}_{2}$ during combustion of typical Chinese coals. Fuel Process. Technol. 2002, 79, 157-169. [CrossRef]

32. Yu, S.; Xie, F.; Jia, B.; Zhang, P. Influence Study of Organic and Inorganic Additive to Coal Combustion Characteristic. Procedia Environ. Sci. 2012, 12, 459-467.

33. Tic, W.J.; Guziałowska-Tic, J.; Junga, R. The impact of catalytic additive for coal fuel on the environmental emissions. Przem. Chem. 2015, 94, 1000-1003.

34. Tic, W.J.; Zadorożny, A. Catalyst for Burning Solid Fuels, Preferably Coal Fuel in the Form of Fine Coal. 2015. PL412525(A1). Available online: https://pl.espacenet.com (accessed on 29 November 2019).

35. Klasy jakości kotłów; PN-EN 303-5:2012; Polish Committee of Standardization: Warszawa, Poland, 2014.

36. Fan, W.; Wu, X.; Guo, H.; Zhu, J.; Liu, P.; Chen, C.; Wang, Y. Experimental study on the impact of adding $\mathrm{NH}_{3}$ on $\mathrm{NO}$ production in coal combustion and the effects of char, coal ash, and additives on $\mathrm{NH}_{3}$ reducing NO under high temperature. Energy 2019, 173, 109-120. [CrossRef]

(C) 2019 by the authors. Licensee MDPI, Basel, Switzerland. This article is an open access article distributed under the terms and conditions of the Creative Commons Attribution (CC BY) license (http://creativecommons.org/licenses/by/4.0/). 